\title{
PERSEPSI MAHASISWA TENTANG PEMBELAJARAN ONLINE “GOOGLE CLASSROOM" PADA MINAT DAN MOTIVASI BELAJAR
}

\author{
Rendika Vhalery ${ }^{1}$ \\ Universitas Indraprasta PGRI \\ Jakarta, Indonesia \\ Rendikavhalery31@gmail.com
}

\author{
Sindi Nur Alfilail ${ }^{2}$ \\ Universitas Indraprasta \\ PGRI \\ Jakarta, Indonesia \\ Sindi.alfilail@gmail.com
}

\author{
Hamzah Robbani ${ }^{3}$ \\ Universitas Indraprasta PGRI \\ Jakarta, Indonesia \\ hamzahrabbani8@gmail.com libertinatalia@gmail.com \\ Liberti Natalia Hia \\ Universitas PGRI \\ Palangka Raya
}

\begin{abstract}
Abstrak
Masa pandemi Covid-19 yang terjadi di Indonesia menyebabkan perubahan sistem belajar secara langsung (tatap muka) menjadi full online yang menyebabkan banyak paradigma atau pandangan baik itu bernilai positif maupun negatif. Realitanya, kebanyakan mahasiswa mengeluh dengan sifat pembelajaran online yang hanya berisi tugas dan terkadang tanpa penjelasan terkait materi yang diajarkan. Secara tidak langsung, hal ini berdampak pada minat belajar dan motivasi belajar mereka. Disisi lain, pembelajaran online seperti google classroom dapat meminimalisir dampak tersebut. Oleh sebab itu, penelitian ini bertujuan untuk mengetahui apakah ada pengaruh persepsi mahasiswa tentang pembelajaran online "google classroom" pada minat belajar mahasiswa? dan apakah ada pengaruh persepsi mahasiswa tentang pembelajaran online "google classroom" pada motivasi belajar mahasiswa?. Penelitian ini dilakukan dan menggunakan populasi serta sampel dari mahasiswa Universitas Indraprasta PGRI dengan teknik pengumpulan data kuesioner melalui google form. Berdasarkan teknik analisis data yang dilakukan didapat hasil penelitan yang menunjukkan bahwa ada pengaruh persepsi mahasiswa tentang pembelajaran online "google classroom" pada minat belajar mahasiswa dan ada pengaruh persepsi mahasiswa tentang pembelajaran online "google classroom" pada motivasi belajar mahasiswa.
\end{abstract}

Kata kunci: Persepsi Mahasiswa, Pembelajaran Online, Google Classroom, Minat Belajar, Motivasi Belajar

\section{PENDAHULUAN}

Masa pandemi Covid-19 yang terjadi di Indonesia hingga saat ini menimbulkan beberapa permasalahan dibidang pendidikan. Permasalahan pertama, sistem belajar secara langsung (tatap muka) menjadi full daring atau online. Dampak perubahan ini sangat dirasakan oleh beberapa guru dan dosen yang ada di Indonesia. Permasalahan kedua, waktu belajar yang sudah pasti (contoh: 3 sks $=2,5 j a m$ ) menjadi lebih fleksibel. Perubahan ini memberikan efek yang mengakibatkan dosen menjadi sulit untuk mengatur waktu dikarenakan harus stand by setiap saat apabila mahasiswa ada yang bertanya. Permasalahan ketiga, hubungan antara mahasiswa dan dosen tidak terbentuk secara nyata dikarenakan pertemuan online. Dari ketiga permasalahan tersebut, yang paling urgent adalah permasalahan petama, yaitu perubahan sistem belajar secara langsung (tatap muka) menjadi full online.

Perubahan sistem belajar secara langsung (tatap muka) menjadi full online menyebabkan banyak paradigma atau pandangan diberbagai pihak (Zhafira et al., 2020). Ada yang mengangap ini sebuah perubahan positif, dengan asumsi bahwa dosen semakin melek teknologi yang bisa sejalan dengan perkembangan masa. Ada juga yang menggangap ini sebagai perubahan negatif, dikarenakan dosen tidak dapat mengetahui secara langsung tentang karakter, kepribadian, sikap, 
atau sifat mahasiswanya. Dan realitanya, selama masa lockdown pandemi Covid-19 terjadi, kebanyakan mahasiswa mengeluh pada sistem pembelajaran yang bersifat online. Pembelajaran yang bersifat online nyatanya hanya tugas dan terkadang tanpa penjelasan terkait materi yang diajarkan. Secara tidak langsung, hal ini berdampak pada minat belajar dan motivasi belajar mereka, karena setiap mahasiswa memiliki minat dan motivasi belajar yang berbeda (Awe \& Benge, 2017; Wilda et al., 2017).

Pratiwi (2015) \& Karina, Syafrina, \& Habibah (2017) menyatakan bahwa minat berkaitan dengan perasaaan seseorang terhadap sesuatu yang timbul karena adanya perasaan senang yang menyebabkan orang tersebut selalu memerhatikan dan mengingatnya secara terus menerus. Lebih lanjut, Ricardo \& Meilani (2017) menjelaskan minat belajar sebagai faktor yang mendorong mahasiswa untuk belajar berdasarkan ketertarikannya pada pembelajaran melalui aspek pembangun motivasi, fenomena yang terbentuk akibat interaksi sosial, dan keterlibatan mahasiswa dalam kegiatan belajar. Ada beberapa cara untuk mengidentifikasi minat mahasiswa ketika tertarik untuk belajar yaitu kesiapan belajar dan kesempatan belajar yang diinginkannya (Pibriana \& Ricoida, 2017), sehingga minat tersebut dapat diukur melalui empat indikator, yaitu ketertarikan untuk belajar, perhatian dalam belajar, motivasi belajar, dan pengetahuan (Andriani \& Rasto, 2016; Siskawati et al., 2016).

Mahasiswa yang memiliki minat belajar rendah apabila tergolong dalam kelompok berikut; 1) tidak fokus pada saat kegiatan pembelajaran berlangsung, 2) tidak mempunyai kemauan untuk mengikuti pelajaran, 3) kurangnya antusias dalam mengikuti kegiatan pembelajaran, 4) bersifat pasif, 5) tidak mendengar atau mencatat apa yang dijelaskan oleh dosen, dan 6) apabila mahasiswa diminta untuk mengajukan pertanyaan atau memberikan tanggapan atas materi yang disampaikan, mahasiswa hanya diam (Prihatin, 2017). Dan apabila mahasiswa memiliki minat belajar tinggi, mereka akan mempunyai perhatian terhadap pelajaran tersebut dan berusaha untuk memperoleh nilai yang bagus (Daniyati, 2015). Untuk mengetahui minat belajar mahasiswa Univesitas Indraprasta PGRI Jakarta, peneliti melakukan wawancara kepada beberapa mahasiswa via telpon atau aplikasi komunikasi. Hasil wawancara mengungkapkan bahwa sebagian besar mahasiswa mempunyai minat yang rendah pada saat proses pembelajaran melalui online. Hal ini disebabkan oleh penjelasan yang seringkali terganggu oleh jaringan, layar handphone terkadang hang, dll.

Dampak lainnya pada motivasi belajar mahasiswa. Menurut Fauziah, Rosnaningsih, \& Azhar (2017), motivasi adalah tindakan secara sadar atau tidak sadar untuk melakukan sesuatu kegiatan untuk mencapai tujuannya. Lebih lanjut, Nugraha, Suyitno, \& Susilaningsih (2017) motivasi belajar adalah sebuah daya penggerak di dalam diri mahasiswa yang menimbulkan kegiatan belajar. Motivasi belajar dapat diklasifikasikan menjadi dua yaitu motivasi instrinsik (yang berasal dari dalam diri) dan motivasi ekstrinsik (yang datang dari luar individu) (Emda, 2018). Hamdu \& Agustina (2011) berpendapat bahwa mahasiswa yang mempunyai motivasi tinggi dalam belajar akan memperoleh hasil cukup baik. Tidak hanya itu, mahasiswa yang mempunyai motivasi tinggi juga dapat menyelesaikan suatu masalah dengan mudah (H. Ulya, 2016). Indikator untuk mengukur motivasi belajar yaitu tekun menghadapi tugas, ulet menghadapi kesulitan, menunjukan minat, mandiri, dan dapat mempertahankan pendapatnya (Suprihatin, 2015).

Untuk mengetahui tingkat motivasi mahasiswa Univesitas Indraprasta PGRI Jakarta. Peneliti juga melakukan studi pendahuluan melalui penyebaran 30 kuesioner kepada mahasiswa Univesitas Indraprasta PGRI Jakarta. Hasil menunjukkan bahwa 20 (66,6\%) mahasiswa memiliki motivasi belajar yang rendah, $5(16,7 \%)$ mahasiswa memiliki motivasi belajar yang sedang, dan $5(16,7 \%)$ mahasiswa memiliki motivasi belajar yang tinggi. artinya, masih banyak mahasiswa yang memiliki motivasi belajar yang rendah.

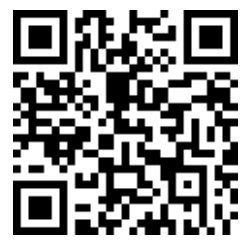

DOI PUBLIKASI https://doi.org/10.37010/int 


\title{
PERSEPSI MAHASISWA TENTANG PEMBELAJARAN ONLINE “GOOGLE CLASSROOM" PADA MINAT DAN MOTIVASI BELAJAR
}

\author{
Rendika Vhalery, Sindi Nur Alfilail, Hamzah Robbani \\ Universitas Indraprasta PGRI
}

Disimpulkan bahwa minat belajar dan motivasi belajar mahasiswa Univesitas Indraprasta PGRI Jakarta berada pada kategori rendah. Hal ini dipengaruhi oleh faktor internal (Lestari, 2017) dan faktor eksternal (Alifah et al., 2019). Salah satu faktor umum dari internal atau eksternal adalah persepsi mahasiswa. Persepsi mahasiswa adalah proses dimana mahasiswa mengartikan, mengevaluasi, menerima, memberi pendapat, dan menguji kepada data dan respons panca indra pada apa yang dilihatnya (Darmaji et al., 2019). Persepsi mahasiswa diukur melalui persepsi kemudahan, kebermanfaatan, dan penerimaan (Mustarin \& Wiharto, 2018). Selain persepsi mahasiswa, Salah satu cara untuk mengatasi masalah itu dengan cara mendesain ulang pembelajaran yang menarik (I. F. Ulya et al., 2016), seperti menggunakan e-learning: google classroom.

Ada banyak penelitian tentang minat belajar dan motivasi belajar. Namun, kebanyakan dari penelitian tersebut menggunakan minat atau motivasi sebagai variabel independen. Tidak banyak peneliti yang menggunakannya sebagai variabel dependen. Penelitian tentang persepsi mahasiswa juga tergolong masih sedikit, apalagi khusus pada e-learning seperti google classroom. Oleh sebab itu, peneliti ingin melakukan penelitian berlandaskan statement tersebut. Untuk mengetahui apakah ada pengaruh persepsi mahasiswa tentang e-learning: google classroom pada minat belajar ?, dan untuk mengetahui apakah ada pengaruh persepsi mahasiswa tentang e-learning: google classroom pada motivasi belajar ?.

\section{METODE}

Penelitian ini adalah penelitian kuantitatif dengan jenis penelitian asosiatif yang menguji pengaruh variabel independen terhadap variabel dependen. Penelitian ini dilakukan pada bulan Juni - Agustus 2020 di Universitas Indraprasta PGRI Jakarta. Populasi dalam penelitian ini adalah mahasiswa Universitas Indraprasta PGRI Jakarta dengan jumlah sampel penelitian sebanyak 198 mahasiswa yang diambil melalui non-probability sampel dengan teknik sampling purposive sampling. Teknik pengumpulan data menggunakan kuesioner online via google form. Instrumen penelitian berdasarkan indikator yang dapat dirincikan sebagai berikut:

Tabel 1. Uji Normalitas Data Penelitian

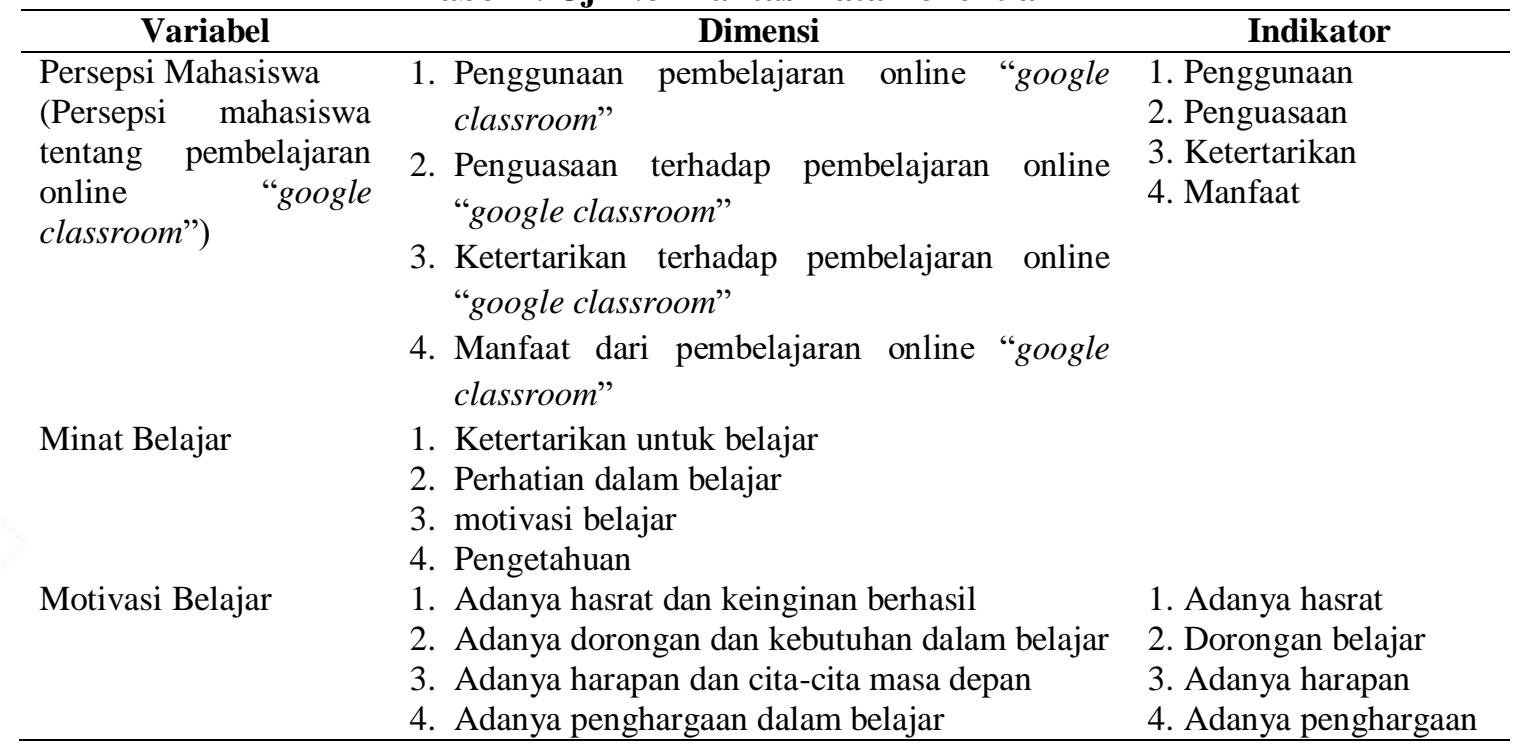


5. Adanya kegiataan yang menarik dalam belajar

6. Adanya lingkungan belajar yang kondusif
5. Ketertarikan belajar

6. Lingkungan belajar yang kondusif

Sumber: Diolah oleh Peneliti (2021)

Skala pengukuran yang digunakan dalam teknik analsis data yaitu skala ordinal yaitu 1 - 5 yang merujuk pada skala likert. Teknik analisis data menggunakan analisis data regresi dengan dua rumus persamaan yaitu $\mathrm{Y}_{1}=\mathrm{a}+\mathrm{bX}$ dan $\mathrm{Y}_{2}=\mathrm{a}+\mathrm{bX}$. Untuk mempermudah perhitungan statistik, peneliti menggunakan software bantuan SPSS versi 24.0.

\section{HASIL DAN PEMBAHASAN}

\section{Hasil}

\section{Uji Asumsi Klasik}

1. Uji Normalitas Data

Uji normalitas data dalam penelitian ini menggunakan rumus kolmogorov-smirnov berbantuan SPSS versi 24.0 dengan ketentuan nilai asymp. sig. (2-tailed). Apabila nilai asymp. sig. (2-tailed) lebih besar (>) dari 0,050 maka data penelitian bersifat normal, sedangkan apabila nilai asymp. sig. (2-tailed) lebih kecil $(<)$ dari 0,050 maka data penelitian bersifat tidak normal. Hasil uji normalitas data penelitian dalam penelitian ini dapat dilihat pada tabel berikut ini:

Tabel 2. Uji Normalitas Data Penelitian

\begin{tabular}{ll|c}
\hline & & Unstandardized Residual \\
\hline $\mathrm{N}$ & & 198 \\
\hline Normal Parameters & Mean &, 0000000 \\
\cline { 2 - 3 } & Std. Deviation & 5,34652155 \\
\hline \multirow{2}{*}{ Most Extreme Differences } & Absolute &, 046 \\
\cline { 2 - 3 } & Positive &, 042 \\
\cline { 2 - 3 } & Negative &,- 046 \\
\hline Test Statistic & &, 046 \\
\hline Asymp. Sig. (2-tailed) & &, 200 \\
\hline Sumber: Data Olahan SPSS 24.0 &
\end{tabular}

Berdasarkan tabel 2 di simpulkan bahwa data penelitian bersifat normal. Hal ini diketahui dari nilai asymp. sig. (2-tailed) lebih besar dari 0,050.

\section{Uji Homogenitas Data}

Selanjutnya dilakukan uji homogenitas data untuk mengetahui data penelitian bersifat homogen (sama) atau bersifat heterogen (tidak sama atau tidak homogen). Hasil uji homogenitas data dapat dilihat pada tabel berikut ini:

Tabel 3. Uji Homogenitas Data Penelitian

\begin{tabular}{lc|c|c|c}
\hline Variabel & Levene Statistic & df1 & df2 & Sig. \\
\hline${\mathrm{X} \mathrm{ke} \mathrm{Y}_{1}}$ & 1,359 & 25 & 165 &, 131 \\
\hline
\end{tabular}




\begin{tabular}{|c|c|c|c|c|}
\hline $\mathrm{X} \mathrm{ke} \mathrm{Y}_{2}$ & 1,237 & 25 & 165 & ,214 \\
\hline
\end{tabular}

Berdasarkan tabel 3 di simpulkan bahwa data penelitian bersifat homogen (sama). Hal ini diketahui dari nilai sig. untuk variabel $\mathrm{X}$ ke $\mathrm{Y}_{1}$ yaitu 0,131 lebih besar dari 0,050 dan nilai sig. untuk variabel $\mathrm{X}_{\mathrm{ke}} \mathrm{Y}_{2}$ yaitu 0,214 lebih besar dari 0,050.

\section{Regresi Linear Sederhana}

Regresi dalam penelitian ini dilakukan dua kali dikarenakan memiliki dua variabel dependen. Artinya, ada dua rumus persamaan regresi linear sederhana yang akan disediakan dalam penelitian ini. Kedua persamaan itu yaitu $Y_{1}=a+b X$ dan $Y_{2}=a+b X$. Hasil persamaan regresi linear ini dapat dilihat pada tabel berikut ini:

Tabel 4. Uji Regresi Linear

\begin{tabular}{|c|c|c|c|c|c|c|}
\hline & \multirow[t]{2}{*}{ Model } & \multicolumn{2}{|c|}{$\begin{array}{l}\text { Unstandardized } \\
\text { Coefficients }\end{array}$} & \multirow{2}{*}{$\begin{array}{c}\text { Standardized } \\
\text { Coefficients } \\
\text { Beta }\end{array}$} & \multirow[t]{2}{*}{$\mathbf{t}$} & \multirow[t]{2}{*}{ Sig. } \\
\hline & & B & Std. Error & & & \\
\hline \multirow[t]{12}{*}{1} & (Constant) $\mathrm{X}$ ke $\mathrm{Y}_{1}$ & 16,139 & 2,279 & & 7,082 & ,000 \\
\hline & $\mathrm{X}$ ke $\mathrm{Y}_{1}$ & 650 & 056 & 641 & 11,697 & 000 \\
\hline & $\mathrm{R}$ & & & 0,641 & & \\
\hline & R Square & & & 0,411 & & \\
\hline & Adjusted R Square & & & 0,408 & & \\
\hline & Std. Error of the Estimate & & & 5,360 & & \\
\hline & (Constant) ${\mathrm{X} \mathrm{ke} \mathrm{Y}_{2}}$ & 38,623 & 3,018 & & 12,797 & ,000 \\
\hline & $\mathrm{X}$ ke $\mathrm{Y}_{2}$ &, 591 &, 074 & 498 & 8,033 & 000 \\
\hline & $\mathrm{R}$ & & & 0,498 & & \\
\hline & R Square & & & 0,248 & & \\
\hline & Adjusted R Square & & & 0,244 & & \\
\hline & Std. Error of the Estimate & & & 7,099 & & \\
\hline
\end{tabular}

Sumber: Data Olahan SPSS 24.0

1. Persepsi mahasiswa tentang pembelajaran online "google classroom" pada minat belajar

Berdasarkan hasil output SPSS pada tabel 4 diketahui bahwa nilai persamaan $\mathrm{Y}_{1}=$ $16,139+0,650 X$. Artinya, apabila nilai $X=0$ maka nilai $Y_{1}$ sebesar 16,139 dan apabila nilai $\mathrm{X}$ naik menjadi $1(\mathrm{X}=1)$ maka nilai $\mathrm{Y}_{1}=16,139+0,650(1), \mathrm{Y}=16,789$ dan seterusnya atau sebaliknya. Nilai $R$ square pada tabel 4 diketahui sebesar 0,411 atau sebesar $41,1 \%$ yang berarti kontribusi persepsi mahasiswa tentang pembelajaran online "google classroom" pada minat belajar sebesar $41,1 \%$, sedangkan 58,9\% merupakan kontribusi diluar variabel yang ada. Hasil output SPSS juga menunjukkan nilai $t_{\text {hitung }}$ sebesar 11,697 dengan nilai signifikansi 0,000 lebih besar dari nilai $t_{\text {tabel }}$ sebesar 1,972 dengan nilai signifikansi 0,050. Kesimpulan dari hasil penelitian ini menunjukkan bahwa Ha diterima dan $\mathrm{H} 0$ ditolak maka adanya pengaruh persepsi mahasiswa tentang pembelajaran online "google classroom" pada minat belajar.

Hasil penelitian ini tidak berbeda jauh dengan hasil penelitian yang dikemukakan oleh Mahrub (2020) yang mengemukakan bahwa terdapat hubungan yang signifikan antara persepsi mahasiswa tentang pembelajaran online terhadap minat belajar mahasiswa selama pandemi covid-19. Sedangkan hasil penelitian yang dikemukakan oleh Ningsih (2020) menyatakan bahwa mayoritas mahasiswa sebanyak 93,5\% lebih menyukai pembelajaran secara offline dikarenakan keterbatasan kuota internet secara terus menerus, pemahaman materi kurang maksimal dan interaksi yang terbatas. Namun, media online yang paling 
diminati mahasiswa saat pembelajaran online yaitu google classroom. Menurut Maskar \& Wulantina (2019) pembelajaran online melalui google classroom dapat meningkatkan interaksi pada proses pembelajaran, sehingga minat belajar mahasiswa dapat distimulus dengan baik. Ketika stimulus ini bekerja pada mahasiswa, hal ini akan memacu persepsi mereka untuk menilai pembelajaran berbasis online ini. Oleh sebab itu, persepsi mahasiswa tentang pembelajaran online via "google classroom" akan berpengaruh terhadap minat belajar mahasiswa.

2. Persepsi mahasiswa tentang pembelajaran online "google classroom" pada motivasi belajar

Berdasarkan hasil output SPSS pada tabel 4 diketahui bahwa nilai persamaan $\mathrm{Y}_{2}=$ $38,623+0,591 X$. Artinya, apabila nilai $X=0$ maka nilai $Y_{2}$ sebesar 38,623 dan apabila nilai $\mathrm{X}$ naik menjadi $1(\mathrm{X}=1)$ maka nilai $\mathrm{Y}_{2}=38,623+0,591(1), \mathrm{Y}=39,214$ dan seterusnya atau sebaliknya. Nilai $R$ square pada tabel 4 diketahui sebesar 0,248 atau sebesar $24,8 \%$ yang berarti kontribusi persepsi mahasiswa tentang pembelajaran online "google classroom" pada motivasi belajar sebesar $24,8 \%$, sedangkan $75,2 \%$ merupakan kontribusi diluar variabel yang ada. Hasil output SPSS juga menunjukkan nilai $t_{\text {hitung }}$ sebesar 8,033 dengan nilai signifikansi 0,000 lebih besar dari nilai $t_{\text {tabel }}$ sebesar 1,972 dengan nilai signifikansi 0,050. Kesimpulan dari hasil penelitian ini menunjukkan bahwa Ha diterima dan $\mathrm{HO}$ ditolak maka adanya pengaruh persepsi mahasiswa tentang pembelajaran online "google classroom" pada motivasi belajar.

Hasil penelitian ini senada dengan hasil penelitian yang didapat oleh Puspitaningsih \& Rachma (2020) yang mengungkapkan bahwa persepsi mahasiswa STIKes Majapahit dalam mengikuti pembelajaran online selama masa pandemi covid-19 yang meliputi 3 aspek (yaitu aspek proses belajar mengajar, kompetensi dosen, dan sarana prasarana secara umum memiliki persepsi yang positif) yang ditunjang dengan dengan motivasi belajar (baik motivasi internal maupun eksternal) yang sebagian besar responden memiliki motivasi yang kuat. Hal ini dikarenakan motivasi merupakan unsur penting yang dapat menjadi faktor kunci untuk meningkatkan gairah belajar para mahasiswa. Maskar \& Wulantina (2019) juga berpendapat bahwa pembelajaran online melalui google classrom juga dapat meningkatkan motivasi belajar. Oleh sebab itu, persepsi mahasiswa tentang pembelajaran online via "google classroom" akan berpengaruh terhadap motivasi belajar mahasiswa.

\section{Pembahasan}

Penyelenggaraan pembelajaran jarak jauh memberikan banyak pembaruan wajah pendidikan. Hamzah (2020) menjelaskan pentingnya tenaga pendidik untuk melakukan perubahan system belajar dengan mengacu pada standar kompetensi tertenu, misalnya pada Standar kompetensi kerja nasional Indonesia bidang metodologi instruktur. Perubahan metode belajar yang terbukti memberikan dampak terhadap motivasi dan minat seharusnya dapat dimitigasi dengan dengan melakukan standardisasi penyelenggaraan pembelajaran jarak jauh. Instrument seperti google classroom dan sejeninsnya merupakan model pembelajaran jarak jauh Asynchronous yang juga menjadi bagian dari standar pembelajaran jarak jauh SKKNI bidang metodologi instruktur.

Sebesar 58,9\% minat belajar mahasiswa dipengaruhi oleh faktor lain selain menggunakan google classroom dan sebesar 75,2\% motivasi belajar dipegaruhi oleh faktor lainya. Hal tersebut menunjukan masih banyak sekali faktor yang harus digali terkait faktor apa saja yang memberikan minat dan motivasi belajar mahasiswa. Vendhi (2020) menjelaskan bahwa pentingnya pemilihan template LBV yang user friendly pada LBV khususnya untuk penilaian

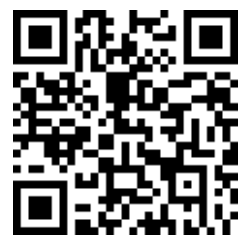

DOI PUBLIKASI https://doi.org/10.37010/int 


\title{
PERSEPSI MAHASISWA TENTANG PEMBELAJARAN ONLINE “GOOGLE CLASSROOM" PADA MINAT DAN MOTIVASI BELAJAR
}

\author{
Rendika Vhalery, Sindi Nur Alfilail, Hamzah Robbani \\ Universitas Indraprasta PGRI
}

formatif. Google classroom dapat saja menjadi instrument terdepan dalam pengelenggaraan pembelajaran jarak jauh, namun tentunya perlu dikaji pada beberapa hal, missal pada template/dashboard yang user friendly apakah sudah terbutki memberi kemudahan, apakah akses pada akun tersebut memberikan kemudahan pendidik dan mahasiswa dalam mendapatkan kepuasan belajar sehingga mahasiswa termotivasi dan memiliki minat terhadap pembelajaran jarak jauh khususnya dengan instrument google classroom.

\section{PENUTUP}

Hasil penelitian menunjukkan bahwa ada pengaruh persepsi mahasiswa tentang pembelajaran online "google classroom" pada minat belajar mahasiswa dan ada pengaruh persepsi mahasiswa tentang pembelajaran online "google classroom" pada motivasi belajar mahasiswa. Adanya pengaruh persepsi mahasiswa tentang pembelajaran online melalui google classrom dikarenakan pembelajaran online memberikan suatu proses pembelajaran yang menyenangkan, menghemat waktu, simpel, dan dapat diakses dimanapun bahkan kapanpun diinginkan oleh user. Proses inilah yang secara tidak langsung dapat menstimulus minat belajar dan motivasi belajar para peserta (siswa, mahasiswa, maupun user lainnya) sehingga mereka mau melakukan aktivitas pembelajaran dan mempunyai pandangan yang positif dari pembelajaran online ini. Disarankan untuk mempersiapkan jenis pembelajaran online lainnya untuk menghindari pembelajaran online yang monoton sehingga mahasiswa terus menikmati pembelajaran online di masa pandemi covid-19.

\section{DAFTAR PUSTAKA}

Alifah, S., Narsih, D., \& Widiyarto, S. (2019). Pengaruh Metode Partisipatori Dan Minat Belajar Terhadap Kemampuan Berwirausaha Siswa Smk. Lectura : Jurnal Pendidikan, 10(1), 66-81. https://doi.org/10.31849/lectura.v10i1.2410

Andriani, R., \& Rasto, R. (2016). Motivasi belajar sebagai determinan hasil belajar siswa. Jurnal Pendidikan Manajemen Perkantoran, 1(1).

Awe, E. Y., \& Benge, K. (2017). Hubungan Antara Minat Dan Motivasi Belajar Dengan Hasil Belajar Ipa Pada Siswa Sd. Journal of Education Technology, 1(4), 231.

Daniyati, N. A. (2015). Hubungan Antara Kemampuan Verbal, Kemampuan Interpersonal, dan Minat Belajar dengan Prestasi Belajar Matematika. Pythagoras: Jurnal Pendidikan Matematika, 10(1), 50-60. https://doi.org/10.21831/pg.v10i1.9109

Darmaji, D., Kurniawan, D. A., Astalini, A., \& Nasih, N. R. (2019). Persepsi Mahasiswa pada Penuntun Praktikum Fisika Dasar II Berbasis Mobile Learning. Jurnal Pendidikan: Teori, Penelitian, Dan Pengembangan, 4(4), 516-523.

Desmita. (2012). Psikologi Perkembangan Peserta Didik. Bandung: Remaja Rosdakarya.

Emda, A. (2018). Kedudukan Motivasi Belajar Siswa Dalam Pembelajaran. Lantanida Journal, $5(2)$.

Fauziah, A., Rosnaningsih, A., \& Azhar, S. (2017). Hubungan Antara Motivasi Belajar Dengan Minat Belajar Siswa Kelas Iv Sdn Poris Gaga 05 Kota Tangerang. Jurnal JPSD, 4(1).

Hamdu, G., \& Agustina, L. (2011). PENGARUH MOTIVASI BELAJAR SISWA TERHADAP PESTASI BELAJAR IPA DI SEKOLAH DASAR (Studi Kasus terhadap Siswa Kelas IV SDN Tarumanagara Kecamatan Tawang Kota Tasikmalaya). Jurnal Penelitian Pendidikan, 12(1), 81-86.

Hamidah, A., Sari, E. N., \& R. S. (2014). Persepsi siswa tentang kegiatan praktikum biologi di laboratorium SMA Negeri Se-Kota Jambi. Sainmatika: Jurnal Sains dan Matematika 
Universitas Jambi, 8(1), 221111.

Iftakhar, S. (2016). Google classroom: what works and how. Journal of Education and Social Sciences, 3(1), 12-18.

Karina, R. M., Syafrina, A., \& Habibah, S. (2017). Hubungan Antara Minat Belajar Dengan Hasil Belajar Siswa Dalam Mata Pelajaran Ipa Pada Kelas V Sd Negeri Garot Geuceu Aceh Besar. Jurnal Ilmiah Pendidikan Guru Sekolah Dasar, 2(1), 61-77. Retrieved from https://media.neliti.com/media/publications/188212-ID-hubungan-antara-minat-belajardengan-has.pdf.

Kiswoyowati, A. (2011). Pengaruh motivasi belajar dan kegiatan belajar siswa terhadap kecakapan hidup siswa. Portal Jurnal Universitas Pendidikan Indonesia, 2(1), 12-16.

Lestari, W. (2017). Pengaruh Kemampuan Awal Matematika dan Motivasi Belajar terhadap Hasil Belajar Matematika. Jurnal Analisa, 3(1), 76. https://doi.org/10.15575/ja.v3i1.1499

Mahrub, N. F. (2020). Pembelajaran Online Terhadap Minat Belajar Universitas Islam Negeri Sulthan Thaha Saifuddin Jambi Selama Pandemi Covid-19.

Maskar, S., \& Wulantina, E. (2019). Persepsi Peserta Didik terhadap Metode Blended Learning dengan Google Classroom. Jurnal Inovasi Matematika, 1(2), 110-121. https://doi.org/10.35438/inomatika.v1i2.156

Mustarin, A., \& Wiharto, M. (2018). Persepsi mahasiswa terhadap penggunaan program elearning berbasis LMS pada Mata Kuliah Teknologi Budidaya Perikanan. Prosiding Hasil Penelitian Lembaga Penelirtian Unhas, 249-253. Retrieved from https://ojs.unm.ac.id/semnaslemlit/article/view/8870.

Nahar, N. I. (2016). Penerapan teori belajar behavioristik dalam proses pembelajaran. NUSANTARA: Jurnal Ilmu Pengetahuan Sosial, 1(1).

Ningsih, S. (2020). Persepsi Mahasiswa Terhadap Pembelajaran Daring Pada Masa Pandemi Covid-19. JINOTEP (Jurnal Inovasi Dan Teknologi Pembelajaran): Kajian Dan Riset Dalam Teknologi Pembelajaran, $\quad 7(2), \quad$ 124-132. https://doi.org/10.17977/um031v7i22020p124

Nugraha, A. J., Suyitno, H., \& Susilaningsih, E. (2017). Analisis Kemampuan Berpikir Kritis Ditinjau dari Keterampilan Proses Sains dan Motivasi Belajar melalui Model PBL. Journal of Primary Education, 6(1).

Nurhasanah, S., \& Sobandi, A. (2016). Minat belajar sebagai determinan hasil belajar siswa. Jurnal Pendidikan Manajemen Perkantoran (JPManper), 1(1), 128-135.

Nurmala, D. A., Tripalupi, L. E., \& Suharsono, N. (2014). Pengaruh motivasi belajar dan aktivitas belajar terhadap hasil belajar akuntansi. Jurnal Pendidikan Ekonomi Undiksha, 4(1).

Pibriana, D., \& Ricoida, D. I. (2017). Analisis pengaruh penggunaan internet terhadap minat belajar mahasiswa ( studi kasus : perguruan tinggi di Kota Palembang ). Jurnal Jatisi, $3(2), 105$.

Pratiwi, N. K. (2015). Pengaruh Tingkat Pendidikan, Perhatian Orang Tua, Dan Minat Belajar Siswa Terhadap Prestasi Belajar Bahasa Indonesia Siswa Smk Kesehatan Di Kota Tangerang. Jurnal Pujangga, $1(2)$.

Pratiwi, R. U. (2021). Pelaksanaan Kurikulum 2013 Pada Pembelajaran Sejarah Kebudayaan Islam Di MTs. Al-Washliyah Medan Krio Kecamatan Sunggal Kabupaten Deli Serdang (Doctoral dissertation, Universitas Islam Negeri Sumatera Utara Medan).

Prihatin, M. satri. (2017). Pengaruh Fasilitas Belajar, Gaya Belajar Dan Minat Belajar Terhadap Hasil Belajar Mata Pelajaran Ekonomi Siswa Kelas X IIS Sma Negeri 1 Seyegan. Jurnal Pendidikan Dan Ekonomi, 6(5), 443-452.

Puspitaningsih, D., \& Rachma, S. (2020). Persepsi Metode Pembelajaran Daring Dengan Motivasi Mahasiswa Stikes Majapahit. Medica Majapahit, 6(2), 59-77.

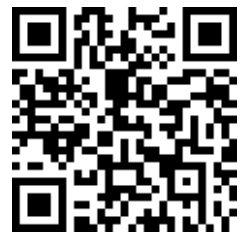

DOI PUBLIKASI https://doi.org/10.37010/int 


\section{Rendika Vhalery, Sindi Nur Alfilail, Hamzah Robbani \\ Universitas Indraprasta PGRI}

Ricardo, \& Meilani, R. I. (2017). Impak Minat dan Motivasi Belajar Terhadap Hasil Belajar Siswa. Jurnal Pendidikan Manajemen Perkantoran, 2(2).

Slameto. (2010). Belajar dan Faktor-Faktor yang Mempengaruhinya. Jakarta: PT. Rineka Cipta. Saifuddin, M. F. (2018). E-learning dalam persepsi mahasiswa. Jurnal Varidika, 29(2), 102-109.

Simbolon, N. (2014). Faktor-faktor yang mempengaruhi minat belajar peserta didik. Elementary School Journal Pgsd Fip Unimed, 1(2).

Siskawati, M., Pargito, P., \& Pujiati, P. (2016). Pengembangan Media Pembelajaran Monopoli Untuk Meningkatkan Minat Belajar Geografi Siswa. Jurnal Studi Sosial, 4(1), 72-80.

Suprihatin, S. (2015). Upaya Guru Dalam Meningkatkan Motivasi Belajar Siswa. PROMOSI (Jurnal Pendidikan Ekonomi), 3(1).

Twentinio, Irenes. (2013). Persepsi Pelanggan Terhadap Pengguna Speedy Jaringan Broad Band Readr (Studi Kasus Di RT 41 Dan RT 42 Perumahan Pusri Sako Palembang). Palembang: Polsri.

Ulya, H. (2016). Profil Kemampuan Pemecahan Masalah Siswa Bermotivasi Belajar Tinggi Berdasarkan Ideal Problem Solving. Jurnal Konseling Gusjigang, 2(1), 90-96. https://doi.org/10.24176/jkg.v2i1.561

Ulya, I. F., Irawati, R., \& Maulana. (2016). Peningkatan Kemampuan Koneksi Matematis Dan Motivasi Belajar Siswa Menggunakan Pendekatan Kontekstual. Jurnal Pena Ilmiah, $1(1)$.

Uno, H.B. (2011). Teori Motivasi dan Pengukurannya. Jakarta : Bumi Aksara.

Wikipedia. Diakses dari: https://id.wikipedia.org/wiki/Google_Kelas, pada tanggal 20 mei 2021, pukul 20:30 WIB.

Wilda, Salwah, \& Ekawati, S. (2017). Pengaruh kreativitas dan minat belajar terhadap hasil belajar matematika siswa. Jurnal Pedagogy, 2(1), 134-144.

Wulandari, B., \& Surjono, H. D. (2013). Pengaruh problem-based learning terhadap hasil belajar ditinjau dari motivasi belajar PLC di SMK. Jurnal Pendidikan Vokasi, 3(2).

Yazid, T. P., \& Ridwan, R. (2018). Proses Persepsi Diri Mahasiswi Dalam Berbusana Muslimah. An-Nida', 41(2), 193-201.

Zhafira, N. H., Ertika, Y., \& Chairiyaton. (2020). Persepsi Mahasiswa Terhadap Perkuliahan Daring Sebagai Sarana Pembelajaran Selama Masa Karantina Covid-19. Jurnal Bisnis Dan Kajian Strategi Manajemen, 4, 37-45. 